\title{
IRRIGATION EFFECTS ON THE SENSORY PERCEPTION OF WINES FROM THREE WHITE GRAPEVINE CULTIVARS TRADITIONAL FROM GALICIA (ALBARIÑO, GODELLO AND TREIXADURA)
}

NOTA TÉCNICA

\author{
EFEITOS DA REGA NA PERCEPÇÃO SENSORIAL DE VINHOS DE TRÊS VARIEDADES BRANCAS \\ TRADICIONAIS DE GALICIA (ALBARIÑO, GODELLO E TREIXADURA)
}

\author{
Emiliano Trigo-Córdoba, Yolanda Bouzas-Cid, Ignacio Orriols-Fernández, José M. Mirás-Avalos*
}

\begin{abstract}
Estación de Viticultura e Enoloxía de Galicia (EVEGA-INGACAL), Ponte San Clodio s/n. 32427, Leiro, Ourense, Spain
*Corresponding author: Tel: +34 988488 033, fax: +34 988488 191, e-mail: jose.manuel.miras.avalos@xunta.es,
\end{abstract}

(Received 12.06.2014. Accepted 21.10.2014)

\section{SUMMARY}

This study aimed to assess the effect of irrigation on the sensory profile of wines from three Galician white grapevine cultivars. Field experiments were carried out in 2011 and 2012 at the research farm of the Estación de Viticultura e Enoloxía de Galicia (EVEGA), where two treatments were imposed: rain-fed and irrigation to the $50 \%$ of potential evapotranspiration. A panel of seven judges tasted the wines in six sessions (one per cultivar and year) for evaluating their sensory profile. In the case of 'Albariño', three descriptors, although not the same for both years, were significantly different between treatments. For 'Godello', several descriptors differed between treatments, and citric was present in both years. In 'Treixadura' white fruit and persistence were present in 2011 and 2012. Several descriptors contributed to the hedonic index, but differed between wines; however, balance was common for all the cultivars and years. In conclusion, 'Albariño' and 'Godello' wines from the rain-fed treatment received higher marks than those from the irrigation treatment; whereas Treixadura wines from the irrigation treatment were better valued.

\section{RESUMO}

Este estudo teve como objetivo avaliar o efeito da rega no perfil sensorial de vinhos procedentes de três castas brancas galegas. As experiências de campo foram realizadas em 2011 e 2012, na quinta da Estación de Viticultura e Enoloxía de Galicia (EVEGA), onde dois tratamentos foram estudados: sem rega e rega a 50\% da evapotranspiração potencial. Uma câmara de sete provadores avaliou os vinhos em seis sessões (uma por variedade e ano) para determinar o seu perfil sensorial. No caso da cultivar 'Albariño', três descritores, embora não sendo os mesmos para ambos os anos, foram significativamente diferentes entre tratamentos. Relativamente à cultivar 'Godello', vários descritores diferiram entre tratamentos, estando o cítrico presente nos dois anos. No caso da cultivar 'Treixadura', a fruta branca e a persistência estiveram presentes em 2011 e 2012. Vários descritores contribuíram para o índice hedónico, mas diferentes entre vinhos; porém, o equilíbrio foi comum para todas as cultivares e anos. Em conclusão, os vinhos das cultivares ‘Albariño' e ‘Godello’ procedentes do tratamento sem rega receberam pontuações mais elevadas que os procedentes do tratamento de rega; pelo contrário, os vinhos de 'Treixadura’ procedentes de tratamentos com rega foram mais valorizados.

Key words: irrigation, Ribeiro, sensory descriptors, tipicity, white wine.

Palavras-chave: rega, Ribeiro, descritores sensoriais, tipicidade, vinho branco.

\section{INTRODUCTION}

Grape maturation and quality are affected by water availability in the vineyard. An excess of water can slow maturation, it may increase yield due to a high berry growth and it may increase must acidity (Jackson and Lombard, 1993). Moreover, it increases grapevine leaf surface, which has been proven to affect sensorial quality of wines (Borghezan et al., 2011). In contrast, water stress might cause a more rapid maturation but reduces yield, berry weight and malic acid content. Since these agronomical and quality attributes are affected by water availability and irrigation management (Gouveia et al., 2012), the customer's sensory perception of the final wine might also be negatively altered. For these reasons, an adequate vineyard irrigation management is required to attain high-quality wines.

In Galicia (NW Spain), Designation of Origin (DO) Ribeiro, located at the North west of the Ourense province, presents an average yearly rainfall of 950 
$\mathrm{mm}$, but drought is observed during the three summer months when rainfall is scarce and temperatures are very high (Consello Regulador Ribeiro, 2014). Soils in this region are sandy-textured with a low water storage capacity and this may cause water stress problems that could negatively affect vine performance and, thus, wine sensory profile.

In Galicia, white grapevine (Vitis vinifera L.) cultivars are mainly grown. Among them, 'Albariño', 'Godello' and 'Treixadura' represent the greatest area of cultivation. These are three autochthonous cultivars used for quality wines and 'Albariño' wines are greatly appreciated worldwide.

'Albariño' is one of the Spanish grape cultivars recognized for giving high-quality white wines and it is the main cultivar from Galicia, although in Ribeiro DO is the fifth white variety in area. It is characterized by its great aromatic potential and is used as a complement for acidity and glycerol as well as for providing aromatic complexity; however, it is also used for making monovarietal wines (Consello Regulador Ribeiro, 2014). Young white wines produced with 'Albariño' are mainly characterised by their fruity and floral odours (Vilanova and Vilariño, 2006).

'Godello' is the third white grapevine cultivar in the region; it provides intense taste to Ribeiro wines, but it does not possess a great aromatic potential. These wines achieve $14 \%$ vol. and maintain total acidity values close to $6 \mathrm{~g} / \mathrm{l}$, hence they are perfectly balanced (Consello Regulador Ribeiro, 2014). 'Godello' wines are straw-gold, fuller than 'Albariño' with well-balanced acidity (Pazo et al., 2004).

'Treixadura' is the main cultivar in Ribeiro DO and it is recognized as one of the most important white grapevine cultivars in Galicia. Its wines are aromatic, with fruity, floral and balsamic notes. They present from 12 to $13.5 \%$ vol., but compensated with 5.5 to 7 $\mathrm{g} / \mathrm{l}$ of total acidity. Thus, these wines are fresh and balanced (Consello Regulador Ribeiro, 2014). Several studies confirmed that secondary aroma compounds possess a relevant contribution to the final aroma of the wines from this variety (López-Tamames et al., 1997; Falqué et al., 2001, 2002).

Global change has increased the variability in the rainfall spatial and temporal distributions in Galicia, as well as increased temperatures (Cruz et al., 2009; Mirás-Avalos et al., 2009) making grapevine growers to use irrigation in their vineyards. Consequently, winemakers are deeply concerned about the influence that irrigation may exert on wine sensory perception.

Vineyard irrigation is a topic widely studied in Spain for red grapevine varieties such as 'Tempranillo' or 'Cabernet Sauvignon' (e.g. Intrigliolo and Castel, 2010; Junquera et al., 2012); however, these studies lack from a sensory evaluation of the final wines and their conclusions do not reflect the possible influence that irrigation treatments may exert on the taster perception of the wines. Moreover, the effects of irrigation on white varieties, specially those from Galicia, have not been studied (Martínez et al., 2012). Thus, it is essential to evaluate the irrigation effects on the sensory profiles of wines from Galician cultivars since this vineyard management strategy may affect their tipicity.

Therefore, the aim of the current study was to assess the effect of irrigation on the sensory profile of wines from Vitis vinifera (L.) cultivars 'Albariño', 'Godello' and 'Treixadura' grown in the Ribeiro DO.

\section{MATERIAL AND METHODS}

\section{Description of the study site and experimental design}

The survey was carried out during two consecutive growing seasons (2011-2012) in an 'Albariño', a 'Godello' and a 'Treixadura' vineyards (Vitis vinifera L.) planted in 1998 on 196-17C rootstock at a spacing of 2.4 by $1.25 \mathrm{~m}$ (3333 vines/ha). The vineyards were located within the experimental farm of the Estación de Viticultura e Enoloxía de Galicia (EVEGA) in Leiro (Ourense, NW Spain) within the Ribeiro DO $\left(42^{\circ} 21.62^{\prime} \mathrm{N}, 8^{\circ} 7.02^{\prime} \mathrm{W}\right.$, elevation $\left.110 \mathrm{~m}\right)$. Vines were trained to a vertical trellis on a single cordon system (10-12 buds per vine) oriented in the EastWest direction. Cultural practices were those commonly applied in the area.

The soil at the site was sandy-loam textured $(61.8 \%$ sand, $19.6 \%$ silt and $18.6 \%$ clay), slightly acid ( $\mathrm{pH}$ $\left(\mathrm{H}_{2} \mathrm{O}\right)$ 6.4) and of medium fertility $(2.8 \%$ organic matter). This soil is classified as an inceptisol (Soil Survey Staff, 2010) with a depth ranging from 80 to $160 \mathrm{~cm}$ depending on the spot within the plot. The available water capacity is, approximately, $100 \mathrm{~mm}$ $\mathrm{m}^{-1}$.

For each cultivar, two treatments were established: rain-fed and drip irrigation to $50 \%$ potential evapotranspiration (ETo). Weather data for calculating ETo, according to Allen et al. (1998), were collected from a weather station located at 200 $\mathrm{m}$ from the experimental site. The field experiment was designed in randomised blocks, each block consisted of 16 plants, half of them were maintained under rain-fed conditions, whereas the other half was submitted to drip irrigation. Each block was replicated three times per cultivar. Guard vines were used in order to avoid border effects. In summary, for each year and cultivar, two treatments and three replicates per treatment were considered.

Plants were irrigated through two emitters $\left(4 \mathrm{~L} \mathrm{~h}^{-1}\right)$ per plant situated $25 \mathrm{~cm}$ to each side of the trunk. The irrigation period lasted from late June to mid August, which is the period of the highest evapotranspiration demand. The number of irrigation events varied from one year to the other, being 8 in 2011 (one per week) and 19 in 2012 (three per week). In the end, the total water amount supplied to the crop was $40 \mathrm{~mm}$ and 50 $\mathrm{mm}$ in 2011 and 2012, respectively. 
Stem water potential was measured at noon on nontranspiring leaves that had been bagged with both plastic sheet and aluminium foil for at least 1 hour before measurements (Choné et al., 2001). These measurements were taken weekly from mid-May until the end of August during the 2012 growing season using a pressure chamber (SoilMoisture Corp, Santa Barbara, CA). One leaf from three vines per treatment and block were used for collecting this parameter, which is considered adequate to assess the water status of Galician vineyards (Mirás-Avalos et al., 2014). These measurements were not performed in 2011 due to lack of equipment.

\section{Wine elaboration}

Grapes from each cultivar and treatment were manually harvested and transported to the experimental winery of EVEGA. The microvinifications were carried out using the usual procedures for white wine vinifications. The grapes from each cultivar and treatment were separately destemmed, crushed and pressed in a pneumatic press. During grape processing $\mathrm{SO}_{2}\left(50 \mathrm{mg} \mathrm{L}^{-1}\right)$ was added to avoid oxidation and for microbiological control. Musts supported a process of static decantation for $24 \mathrm{~h}$ at $10^{\circ} \mathrm{C}$. Then, the musts were fermented in $35 \mathrm{~L}$ stainless steel tanks (three replications per cultivar and treatment), commercial yeast (Lamothe-Abiet, Saccharomyces Cerevisae, Excelent FW) was added at a rate of $20 \mathrm{~g} \mathrm{hL}^{-1}$. Density and temperature of fermentations were daily monitored. A tartaric stabilization was carried out in a cool storage room at $4{ }^{\circ} \mathrm{C}$ for one month. Finally, the wines were filtered, bottled and stored.

\section{Analytical determinations}

Must attributes (total soluble contents, $\mathrm{pH}$ and titratable acidity) were determined using the official methods for must analysis (OIV, 2009). Standard attributes of wines (alcohol content, $\mathrm{pH}$, titratable acidity, tartaric, malic and lactic acids) were determined by Fourier transform infrared spectrometry using a Bacchus II analyzer (TDI, Barcelona-Spain) calibrated according to the official methods for wine analysis (OIV, 2009). A Crison titrator Model TitroMatic 1S (Barcelona, Spain) was used for determining total and free sulphur dioxide by redox titration with potentiometric detection.

\section{Sensory analysis}

Sensory evaluation of wines was performed by seven judges with experience in tasting Galician white wines. Experienced tasters are considered to be better than consumers or trained panelists at communicating and describing what they like (Perrin et al., 2007; Hopfer and Heymann, 2014). In this particular case, the panel of judges consisted of five males and two females between 30 and 62 years old. These individuals were enologists and technicians either from EVEGA or from Galician commercial wineries.
A scorecard including qualitative (cannot be measured) descriptors (4 for colour, 10 for aroma) and 7 quantitative (those that can be objectively measured) attributes for taste was used, as proposed by Odello et al. (2007). The descriptors considered were specifically chosen for Galician white wines from previous works of several authors (Vilanova, 2006; Vilanova et al., 2008, 2013) and were scored from 0 (absence) to 9 (very intense). The descriptors included in this scorecard were divided into the three following aspects: i) colour attributes (colour intensity, yellow reflections, green reflections, and limpidity); ii) aroma attributes (intensity, floral, fresh fruit, white fruit, dry fruit, tropical, citric, herbaceous, terpenic, and persistence); and iii) mouth attributes (sweet, acid, bitter, softness, balance, alcohol, and body). Furthermore, tasters were asked to provide a mark for the global quality of the wine.

Each wine sample $(30 \mathrm{~mL})$ was served, at $12{ }^{\circ} \mathrm{C}$, in a standard wine glass, as required by the ISO 3591 standard (ISO, 1977), and was coded in order to prevent tasters from knowing its origin. A tasting session per cultivar was carried out. In these sessions, seven wines were served: one from each replicate of the rain-fed treatment (three in total), one from each replicate of the irrigation treatment (three in total) and one repeated from one of the treatments in order to assess the repeatability in the response of the tasters. For each attribute and judge, the difference between the value given to one sample and that given to its repeated sample was calculated and the deviation for each judge was computed. In this experiment, all the judges obtained good values (low deviations) for this repeatability test.

The tasting sessions were held in different days (April and May each vintage) at the tasting room of EVEGA that fulfils the requirements of the ISO 8589 standard (ISO, 1988).

\section{Statistical analysis}

One-way ANOVA was used to check the differences on basic wine attributes taking into account the irrigation treatment as a factor. Data were processed using Big Sensory Soft 1.02 (Centro Studi Assagiatori, Brescia, Italy) (Odello et al., 2007), which allowed us to calculate a hedonic index (Odello et al., 2009). This index represents a summary of the values for the descriptors and it allows us to determine the overall quality of the samples tasted by the judges. It is obtained as the average of the marks assigned by the panel to each of the descriptors of each sample. These marks are averaged for the whole panel providing a single value of hedonic index (between 0 and 9) for each sample. Furthermore, the marks assigned by each judge to the mouth attributes were correlated (using Pearson's linear correlation) to the hedonic index in order to estimate which ones of these attributes were affecting significantly the hedonic index computation. The descriptors with coefficients greater than 0.5 were considered to exert 
a significant influence on the estimation of the hedonic index of a given wine.

The non-parametric Friedman test was used to analyse which descriptors were different between rain-fed and irrigation treatments and which of them contributes significantly to the hedonic index. For doing this, attributes are ranked using the median of the values given by the tasters in such a way that those attributes with higher marks are given the highest rank and those attributes with low values are given the lowest rank. Then, these ranks are ordered; then, these ranks are summed for each descriptor and used for the Friedman test.

\section{RESULTS AND DISCUSSION}

\section{Weather data and water status of the vines}

In 2011, the annual mean air temperature was 14.02 ${ }^{\circ} \mathrm{C}$ and total rainfall amounted to $880 \mathrm{~mm}$; whereas in 2012, the mean air temperature was $13.06{ }^{\circ} \mathrm{C}$ and total rainfall was $841 \mathrm{~mm}$, due to a dry winter. For the growing season (April to September), mean air temperatures were $18.5^{\circ} \mathrm{C}$ and $17.1^{\circ} \mathrm{C}$ for 2011 and 2012, respectively. Potential evapotranspiration (ETo) during the growing season was $503.13 \mathrm{~mm}$ in 2011 and $697.76 \mathrm{~mm}$ in 2012.
In 2012, water status of the rain-fed and irrigated vines differed from the beginning of the supplementary water applications. Hence, in the case of 'Albariño', stem water potentials ranged from $0.14 \mathrm{MPa}$ to $-1.02 \mathrm{MPa}$ in the case of the rain-fed vines, whereas they ranged from $-0.14 \mathrm{MPa}$ to -0.81 $\mathrm{MPa}$ in the irrigated ones. In the case of 'Godello', the differences were smaller since rain-fed vines stem water potentials varied from $-0.13 \mathrm{MPa}$ to $-0.68 \mathrm{MPa}$ and those of the irrigated vines oscillated between $0.14 \mathrm{MPa}$ to $-0.40 \mathrm{MPa}$. 'Treixadura' rain-fed vines presented stem water potentials varying from -0.19 $\mathrm{MPa}$ to $-0.92 \mathrm{MPa}$ whereas those irrigated from $0.17 \mathrm{MPa}$ to $-0.66 \mathrm{MPa}$. These values differed between treatments from the end of July to August.

Information about physiological and yield parameters for the 2011 growing season can be found elsewhere (Mirás-Avalos et al., 2012).

\section{Must composition}

Musts attributes were similar between treatments for the three studied cultivars (Table I). However, certain differences were observed between years for each variety.

Table I

Must parameters for 'Albariño’, ‘Godello’ and ‘Treixadura’ cultivars grown under two treatments (mean \pm standard deviation, $\mathrm{n}=3$ ). P-values from ANOVA are also provided

Parâmetros dos mostos de 'Albariño', ‘Godello’ e 'Treixadura' cultivados sobre os dois tratamentos (média \pm desvio padrão; $n=3$ ). São também apresentados os valores de $p$ da ANOVA

\begin{tabular}{|c|c|c|c|c|c|}
\hline Cultivar & Vintage & Treatment & $\begin{array}{c}\text { Total acidity } \\
(\mathrm{g} / \mathrm{L})\end{array}$ & $\begin{array}{c}\text { Soluble solids } \\
\left({ }^{\circ} \text { Brix }\right)\end{array}$ & $\mathrm{pH}$ \\
\hline \multirow[t]{6}{*}{ Albariño } & \multirow[t]{3}{*}{2011} & Rain-fed & $5.8 \pm 0.2$ & $24.1 \pm 0.6$ & $3.41 \pm 0.0$ \\
\hline & & Irrigated & $5.9 \pm 0.4$ & $24.4 \pm 0.6$ & $3.39 \pm 0.1$ \\
\hline & & $p$-value & 0.56 & 0.45 & 0.50 \\
\hline & \multirow[t]{3}{*}{2012} & Rain-fed & $8.4 \pm 0.3$ & $22.9 \pm 0.1$ & $3.05 \pm 0.05$ \\
\hline & & Irrigated & $8.9 \pm 0.3$ & $22.6 \pm 0.5$ & $3.01 \pm 0.02$ \\
\hline & & p-value & 0.09 & 0.36 & 0.20 \\
\hline \multirow[t]{6}{*}{ Godello } & \multirow[t]{3}{*}{2011} & Rain-fed & $6.2 \pm 0.8$ & $23.0 \pm 1.2$ & $3.31 \pm 0.09$ \\
\hline & & Irrigated & $5.3 \pm 0.5$ & $24.6 \pm 2.3$ & $3.48 \pm 0.09$ \\
\hline & & p-value & 0.06 & 0.22 & 0.02 \\
\hline & \multirow[t]{3}{*}{2012} & Rain-fed & $7.7 \pm 0.7$ & $22.3 \pm 0.6$ & $3.22 \pm 0.10$ \\
\hline & & Irrigated & $8.2 \pm 0.7$ & $22.0 \pm 0.6$ & $3.14 \pm 0.09$ \\
\hline & & p-value & 0.45 & 0.65 & 0.44 \\
\hline \multirow[t]{6}{*}{ Treixadura } & \multirow[t]{3}{*}{2011} & Rain-fed & $4.0 \pm 0.3$ & $24.5 \pm 1.5$ & $3.85 \pm 0.13$ \\
\hline & & Irrigated & $4.3 \pm 0.4$ & $23.2 \pm 1.5$ & $3.77 \pm 0.11$ \\
\hline & & $p$-value & 0.25 & 0.18 & 0.28 \\
\hline & \multirow[t]{3}{*}{2012} & Rain-fed & $5.6 \pm 0.6$ & $22.2 \pm 1.9$ & $3.42 \pm 0.15$ \\
\hline & & Irrigated & $5.7 \pm 0.4$ & $22.5 \pm 1.3$ & $3.39 \pm 0.08$ \\
\hline & & $p$-value & 0.83 & 0.81 & 0.80 \\
\hline
\end{tabular}


For instance, 'Albariño' musts were more acid in 2012 than in 2011 and also presented lower total soluble solids content in 2012 than in 2011. However, no significant differences between treatments were observed in any of the years considered in this study (Table I).

In the case of 'Godello' musts, in 2011 musts from the irrigated treatment presented a significantly higher $\mathrm{pH}$ than those from the rain-fed treatment (Table I). This difference was not observed in 2012, when musts from both treatments showed similar attributes.

In the case of 'Treixadura', must attributes were very similar between treatments for both years accounted in this study (Table I).

\section{Wine composition}

For the three cultivars, general attributes of wines were very similar between both rain-fed and irrigation treatments (Tables II, III and IV). In the case of 'Albariño', no significant differences for any of the attributes were observed in 2012; however, in 2011, lactic acid content was greater under rain-fed conditions and glycerol content was higher in wines from the irrigation treatment (Table II). Lactic acid is produced by malolactic fermentation, which in this study was not induced but may have commenced when the wines were bottled. The differences in the lactic acid content might have caused a reduction in fruity aromas of some wines and may have exerted an influence in the sensory appreciation of the wines.

Table II

General analysis for 'Albariño' wines (mean \pm standard deviation; $\mathrm{n}=3$ )

Análises gerais dos vinhos de 'Albariño' (média \pm desvio padrão; $n=3$ )

\begin{tabular}{|l|l|l|l|l|}
\hline \multirow{2}{*}{ Wine attribute } & \multicolumn{2}{|c|}{2011} & \multicolumn{2}{c|}{2012} \\
\cline { 2 - 5 } & \multicolumn{1}{|c|}{ Rain-fed } & \multicolumn{1}{c|}{ Irrigated } & \multicolumn{1}{c|}{ Rain-fed } & \multicolumn{1}{c|}{ Irrigated } \\
\hline Alcoholic content (\% vol) & $14.03 \pm 0.61 \mathrm{a}$ & $13.47 \pm 0.58 \mathrm{a}$ & $13.80 \pm 0.30 \mathrm{a}$ & $13.63 \pm 0.31 \mathrm{a}$ \\
\hline Reducing sugars (g/L) & $4.30 \pm 1.49 \mathrm{a}$ & $4.73 \pm 1.59 \mathrm{a}$ & $2.03 \pm 0.21 \mathrm{a}$ & $2.07 \pm 0.21 \mathrm{a}$ \\
\hline Total acidity (g/L) & $7.47 \pm 0.40 \mathrm{a}$ & $7.83 \pm 0.25 \mathrm{a}$ & $9.47 \pm 0.47 \mathrm{a}$ & $9.57 \pm 0.06 \mathrm{a}$ \\
\hline Volatile acidity (g/L) & $0.45 \pm 0.09 \mathrm{a}$ & $0.48 \pm 0.10 \mathrm{a}$ & $0.20 \pm 0.02 \mathrm{a}$ & $0.20 \pm 0.03 \mathrm{a}$ \\
\hline pH & $3.15 \pm 0.15 \mathrm{a}$ & $3.15 \pm 0.07 \mathrm{a}$ & $2.94 \pm 0.10 \mathrm{a}$ & $2.90 \pm 0.04 \mathrm{a}$ \\
\hline Malic acid (g/L) & $1.63 \pm 0.35 \mathrm{a}$ & $1.57 \pm 0.06 \mathrm{a}$ & $2.41 \pm 0.23 \mathrm{a}$ & $2.28 \pm 0.09 \mathrm{a}$ \\
\hline Tartaric acid (g/L) & $4.20 \pm 0.79 \mathrm{a}$ & $4.60 \pm 0.10 \mathrm{a}$ & $5.33 \pm 0.63 \mathrm{a}$ & $5.68 \pm 0.23 \mathrm{a}$ \\
\hline Lactic acid (g/L) & $2.00 \pm 2.12 \mathrm{a}$ & $0.35 \pm 0.07 \mathrm{~b}$ & $0.18 \pm 0.08 \mathrm{a}$ & $0.10 \pm 0.00 \mathrm{a}$ \\
\hline Free $\mathrm{SO}_{2}(\mathrm{mg} / \mathrm{L})$ & $5.00 \pm 4.24 \mathrm{a}$ & $2.00 \pm 0.00 \mathrm{a}$ & $5.00 \pm 0.00 \mathrm{a}$ & $5.00 \pm 0.00 \mathrm{a}$ \\
\hline Total $\mathrm{SO}_{2}(\mathrm{mg} / \mathrm{L})$ & $32.67 \pm 19.09 \mathrm{a}$ & $27.67 \pm 9.07 \mathrm{a}$ & $32.00 \pm 31.11 \mathrm{a}$ & $51.50 \pm 12.02 \mathrm{a}$ \\
\hline Glycerol $(\mathrm{g} / \mathrm{L})$ & $4.80 \pm 0.00 \mathrm{a}$ & $5.80 \pm 0.14 \mathrm{~b}$ & $5.97 \pm 0.12 \mathrm{a}$ & $5.77 \pm 0.50 \mathrm{a}$ \\
\hline
\end{tabular}

${ }^{\mathrm{a}}$ As tartaric equivalents; ${ }^{\mathrm{b}}$ As acetic equivalents; Means followed by the same letters in the row within the same year are not significantly different at $\mathrm{p}<0.05$.

In addition, 'Godello' wines did not present any significant difference for any of the attributes considered (Table III), except for lactic acid and glycerol in 2011, when the wine from rain-fed treatment presented greater glycerol content than that of the irrigation treatment and the opposite was observed for the lactic acid content.

Finally, in 'Treixadura' wines, total acidity was higher under irrigation in 2011 (Table IV), whereas $\mathrm{pH}$ was lower. The rest of the attributes did not present significant differences between treatments (Table V).

Nevertheless, wines from the irrigation treatment tended to present lower alcoholic contents and higher total acidities than those from the rain-fed treatment. This trend was observed for the three cultivars and has been previously reported for Spanish red grapevine varieties (e.g. Intrigliolo and Castel, 2010).

\section{Sensory profile of the wines}

Since no differences were observed for any of the colour attributes considered for any of the wines analyzed, data on colour descriptors are not presented here and only information concerning aroma and mouth attributes is reported.

In the case of 'Albariño' wines from 2011, significant differences between treatments were detected for several descriptors. Wines from the rain-fed treatment presented higher marks for softness, balance and wine global quality; whereas those from the irrigation treatment were considered more acid and with herbaceous and terpenic notes (Figure 1). This indicates that rain-fed wines were better valued by tasters. 
Table III

General analysis for 'Godello’ wines (mean \pm standard deviation; $\mathrm{n}=3$ )

Análises gerais dos vinhos de 'Godello’ (média \pm desvio padrão; $n=3$ )

\begin{tabular}{|l|l|l|l|l|}
\hline \multirow{2}{*}{ Wine attribute } & \multicolumn{2}{c}{2011} & \multicolumn{2}{c|}{2012} \\
\cline { 2 - 5 } & \multicolumn{1}{|c}{ Rain-fed } & Irrigated & Rain-fed & Irrigated \\
\hline Alcoholic content (\% vol) & $13.63 \pm 0.39 \mathrm{a}$ & $14.10 \pm 0.63 \mathrm{a}$ & $13.62 \pm 0.56 \mathrm{a}$ & $13.33 \pm 0.45 \mathrm{a}$ \\
\hline Reducing sugars (g/L) & $3.32 \pm 2.44 \mathrm{a}$ & $3.45 \pm 2.21 \mathrm{a}$ & $3.00 \pm 2.27 \mathrm{a}$ & $3.17 \pm 1.97 \mathrm{a}$ \\
\hline Total acidity (g/L) & $6.68 \pm 0.56 \mathrm{a}$ & $7.08 \pm 0.40 \mathrm{a}$ & $7.43 \pm 0.64 \mathrm{a}$ & $8.13 \pm 0.81 \mathrm{a}$ \\
\hline Volatile acidity (g/L) & $0.37 \pm 0.10 \mathrm{a}$ & $0.35 \pm 0.09 \mathrm{a}$ & $0.32 \pm 0.04 \mathrm{a}$ & $0.32 \pm 0.03 \mathrm{a}$ \\
\hline pH & $3.15 \pm 0.13 \mathrm{a}$ & $3.15 \pm 0.08 \mathrm{a}$ & $3.08 \pm 0.17 \mathrm{a}$ & $2.97 \pm 0.15 \mathrm{a}$ \\
\hline Malic acid (g/L) & $1.23 \pm 0.21 \mathrm{a}$ & $1.28 \pm 0.13 \mathrm{a}$ & $1.79 \pm 0.34 \mathrm{a}$ & $1.81 \pm 0.06 \mathrm{a}$ \\
\hline Tartaric acid (g/L) & $4.18 \pm 0.68 \mathrm{a}$ & $4.42 \pm 0.63 \mathrm{a}$ & $4.16 \pm 1.10 \mathrm{a}$ & $4.87 \pm 1.09 \mathrm{a}$ \\
\hline Lactic acid (g/L) & $0.38 \pm 0.15 \mathrm{a}$ & $1.22 \pm 0.40 \mathrm{~b}$ & $0.31 \pm 0.20 \mathrm{a}$ & $0.20 \pm 0.17 \mathrm{a}$ \\
\hline Free $\mathrm{SO}_{2}(\mathrm{mg} / \mathrm{L})$ & $4.50 \pm 3.54 \mathrm{a}$ & $3.00 \pm 1.63 \mathrm{a}$ & $5.00 \pm 0.00 \mathrm{a}$ & $5.00 \pm 0.00 \mathrm{a}$ \\
\hline Total SO $(\mathrm{mg} / \mathrm{L})$ & $28.50 \pm 23.79 \mathrm{a}$ & $21.50 \pm 4.76 \mathrm{a}$ & $45.00 \pm 7.21 \mathrm{a}$ & $44.33 \pm 10.07 \mathrm{a}$ \\
\hline Glycerol (g/L) & $6.10 \pm 0.61 \mathrm{a}$ & $5.25 \pm 0.65 \mathrm{~b}$ & $4.67 \pm 0.50 \mathrm{a}$ & $4.70 \pm 0.56 \mathrm{a}$ \\
\hline
\end{tabular}

${ }^{\mathrm{a}}$ As tartaric equivalents; ${ }^{\mathrm{b}}$ As acetic equivalents; Means followed by the same letters in the row within the same year are not significantly different at $\mathrm{p}<0.05$.

Table IV

General analysis for 'Treixadura' wines (mean \pm standard deviation; $\mathrm{n}=3$ )

Análises gerais dos vinhos de 'Treixadura' (média \pm desvio padrão; $n=3$ )

\begin{tabular}{|c|c|c|c|c|}
\hline \multirow[t]{2}{*}{ Wine attribute } & \multicolumn{2}{|c|}{2011} & \multicolumn{2}{|c|}{2012} \\
\hline & Rain-fed & Irrigated & Rain-fed & Irrigated \\
\hline Alcoholic content (\% vol) & $15.00 \pm 0.70 \mathrm{a}$ & $13.50 \pm 1.45 \mathrm{a}$ & $13.40 \pm 0.96 \mathrm{a}$ & $13.47 \pm 0.64 \mathrm{a}$ \\
\hline Reducing sugars (g/L) & $2.10 \pm 1.40 \mathrm{a}$ & $0.90 \pm 0.26 \mathrm{a}$ & $0.90 \pm 0.20 \mathrm{a}$ & $1.43 \pm 0.45 \mathrm{a}$ \\
\hline Total acidity $(\mathrm{g} / \mathrm{L})^{\mathrm{a}}$ & $4.90 \pm 0.20 \mathrm{a}$ & $5.87 \pm 0.64 b$ & $6.60 \pm 0.62 \mathrm{a}$ & $6.87 \pm 0.25 \mathrm{a}$ \\
\hline Volatile acidity (g/L) ${ }^{b}$ & $0.40 \pm 0.00 \mathrm{a}$ & $0.35 \pm 0.13 \mathrm{a}$ & $0.30 \pm 0.14 \mathrm{a}$ & $0.25 \pm 0.07 \mathrm{a}$ \\
\hline $\mathrm{pH}$ & $3.70 \pm 0.10 \mathrm{a}$ & $3.43 \pm 0.16 b$ & $3.41 \pm 0.26 \mathrm{a}$ & $3.34 \pm 0.09 \mathrm{a}$ \\
\hline Malic acid (g/L) & $2.60 \pm 0.80 \mathrm{a}$ & $3.20 \pm 0.72 \mathrm{a}$ & $2.29 \pm 0.19 \mathrm{a}$ & $2.09 \pm 0.53 \mathrm{a}$ \\
\hline Tartaric acid (g/L) & $1.70 \pm 0.20 \mathrm{a}$ & $1.80 \pm 0.10 \mathrm{a}$ & $3.23 \pm 0.81 \mathrm{a}$ & $3.52 \pm 0.10 \mathrm{a}$ \\
\hline Lactic acid (g/L) & $0.60 \pm 0.00 \mathrm{a}$ & $0.50 \pm 0.00 b$ & $0.44 \pm 0.16 \mathrm{a}$ & $0.61 \pm 0.39 \mathrm{a}$ \\
\hline Free $\mathrm{SO}_{2}(\mathrm{mg} / \mathrm{L})$ & $7.00 \pm 0.00$ & Not detected & $5.00 \pm 0.00 \mathrm{a}$ & $5.00 \pm 0.00 \mathrm{a}$ \\
\hline Total $\mathrm{SO}_{2}(\mathrm{mg} / \mathrm{L})$ & $64.70 \pm 17.50 \mathrm{a}$ & $38.33 \pm 11.93 \mathrm{~b}$ & $21.00 \pm 0.00 a$ & $21.00 \pm 0.00 a$ \\
\hline Glycerol (g/L) & $6.00 \pm 0.00$ & Not detected & $5.57 \pm 1.08 \mathrm{a}$ & $5.37 \pm 0.57 \mathrm{a}$ \\
\hline
\end{tabular}

${ }^{a}$ As tartaric equivalents; ${ }^{b}$ As acetic equivalents; Means followed by the same letters in the row within the same year are not significantly different at $\mathrm{P}<0.05$.

Table V

Hedonic index for 'Albariño’, ‘Godello’ and 'Treixadura’ wines from rain-fed and irrigated vines in the 2011 and 2012 vintages Índice hedónico relativo aos vinhos de 'Albariño', 'Godello' and 'Treixadura' produzidos com uva de vinhas regadas e não regadas das colheitas de 2011 e 2012

\begin{tabular}{|l|c|c|c|c|c|c|}
\hline & \multicolumn{2}{|c|}{ Albariño } & \multicolumn{2}{c|}{ Godello } & \multicolumn{2}{c|}{ Treixadura } \\
\cline { 2 - 7 } & 2011 & 2012 & 2011 & 2012 & 2011 & 2012 \\
\hline Rain-fed & $4.66 \mathrm{a}$ & $4.42 \mathrm{a}$ & $4.92 \mathrm{a}$ & $4.65 \mathrm{a}$ & $4.38 \mathrm{a}$ & $4.05 \mathrm{a}$ \\
\hline Irrigated & $4.40 \mathrm{~b}$ & $4.28 \mathrm{a}$ & $4.20 \mathrm{~b}$ & $4.27 \mathrm{~b}$ & $4.36 \mathrm{a}$ & $4.10 \mathrm{a}$ \\
\hline
\end{tabular}

Means followed by the same letters in the column within the same year are not significantly different at $\mathrm{p}<0.05$ 


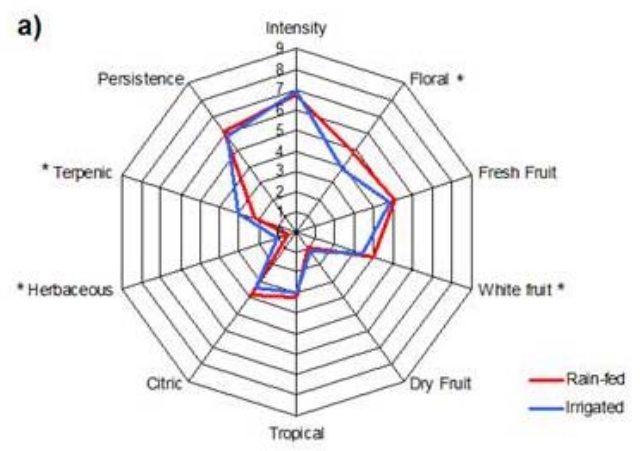

b)

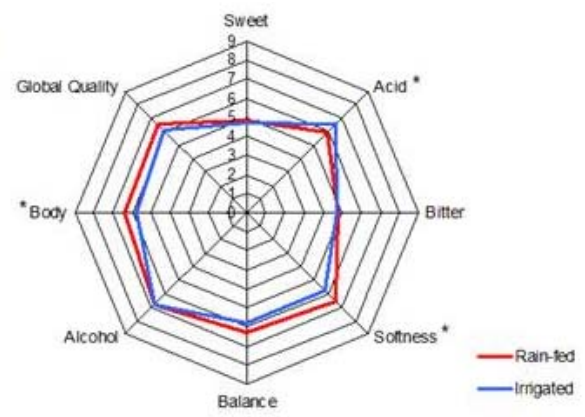

Figure 1. Sensory profiles of 'Albariño' wines from 2011 as a function of the irrigation treatment: a) aroma attributes; b) mouth attributes and global quality. Descriptors marked with an asterisk differed significantly between treatments $(\mathrm{p}<0.05)$.

Perfis sensoriais dos vinhos 'Albariño' 2011 em relação ao tratamento de rega: a) atributos do aroma; b) atributos gustativos e qualidade global. Os descritores marcados com um asterisco diferiram significativamente entre tratamentos $(p<0.05)$.

In the case of 2012, 'Albariño' wines from the rainfed treatment presented white fruit, tropical and terpenic notes; whereas those from the irrigation treatment did not stand out for any descriptor (Figure 2). Hence, tasters gave higher marks to wines from the rain-fed treatment. The descriptors pointed out by the tasters were in accordance with those considered the most important by Vilanova et al. (2008) for 'Albariño' o wines of different vintages.

For 'Godello' wines from 2011, the samples from the rain-fed treatment achieved higher marks for the following descriptors: floral, fresh fruit, citric, sweet, softness, balance, body and wine global quality. In contrast, wines from the irrigation treatment presented herbaceous notes (Figure 3), which are usually considered as negative. As well as for 'Albariño' wines, 'Godello' wines from the rain-fed treatment received higher marks than those from the irrigation treatment, indicating that agricultural practices influence aroma and taste of the final wine (GarcíaMuñoz et al., 2014).

'Godello' wines from 2012 showed, in the case of those from the rain-fed treatment, white fruit, citric, terpenic, acid and bitter notes; attributes that made differences between 'Godello' wines in a former consumer study by Vilanova (2006). Tasters highlighted the dry fruit and sweet notes as well as the softness of the wines from the irrigation treatment (Figure 4). In the end, tasters gave higher marks to wines from the rain-fed treatment.

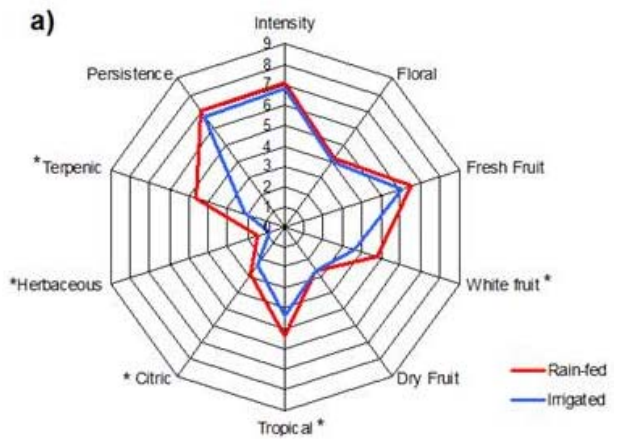

b)

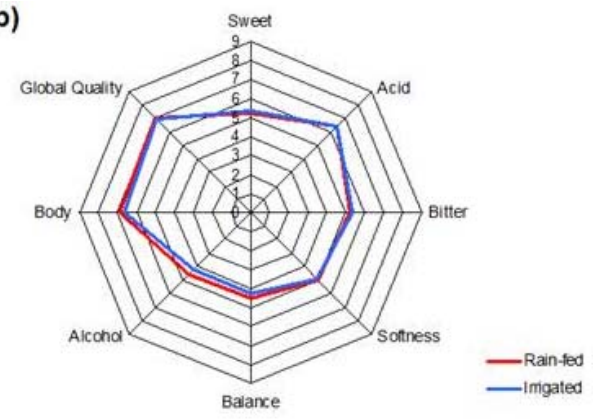

Figure 2. Sensory profiles of 'Albariño' wines from 2012 as a function of the irrigation treatment: a) aroma attributes; b) mouth attributes and global quality. Descriptors marked with an asterisk differed significantly between treatments $(\mathrm{p}<0.05)$.

Perfis sensoriais dos vinhos 'Albariño' 2012 em relação ao tratamento de rega: a) atributos do aroma; b) atributos gustativos e qualidade global. Os descritores marcados com um asterisco diferiram significativamente entre tratamentos $(p<0.05)$.
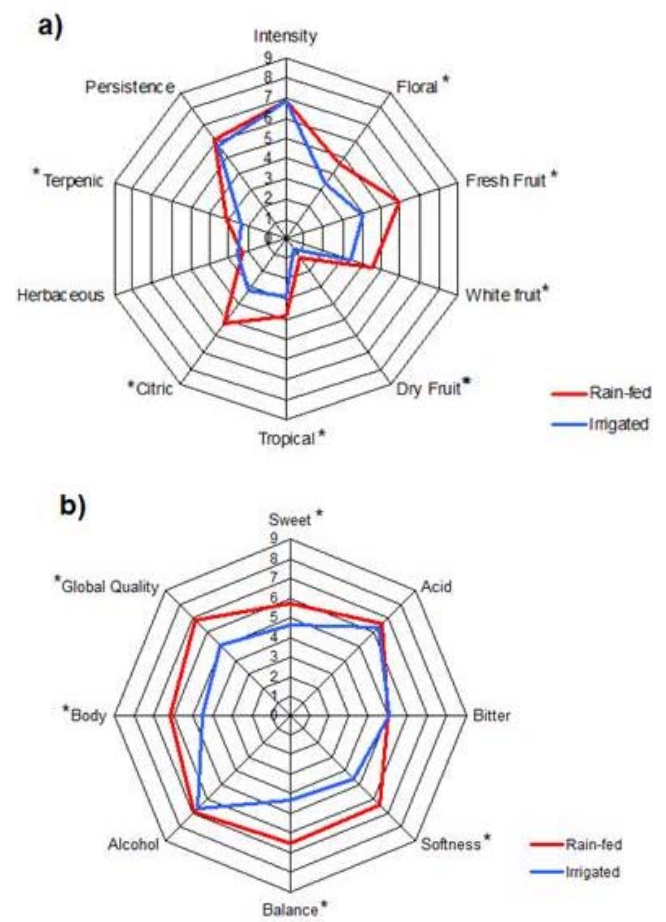

Figure 3. Sensory profiles of 'Godello’ wines from 2011 as a function of the irrigation treatment: a) aroma attributes; b) mouth attributes and global quality. Descriptors marked with an asterisk differed significantly between treatments $(\mathrm{p}<0.05)$.

Perfis sensoriais dos vinhos 'Godello' 2011 em relação ao tratamento de rega: a) atributos do aroma; b) atributos gustativos e qualidade global. Os descritores marcados com um asterisco diferiram significativamente entre tratamentos $(p<0.05)$. 
a)

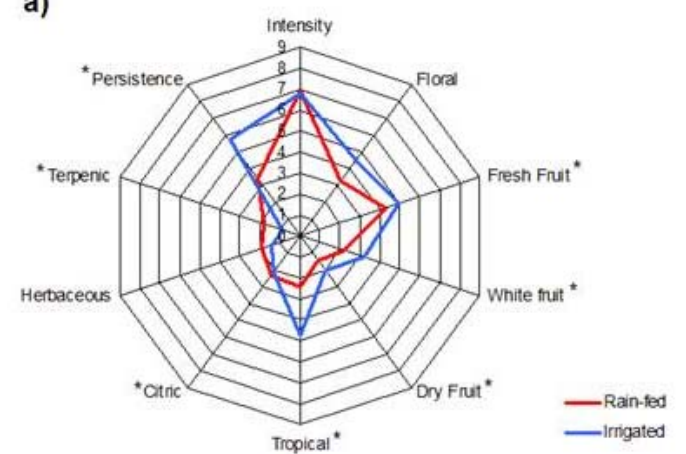

b)

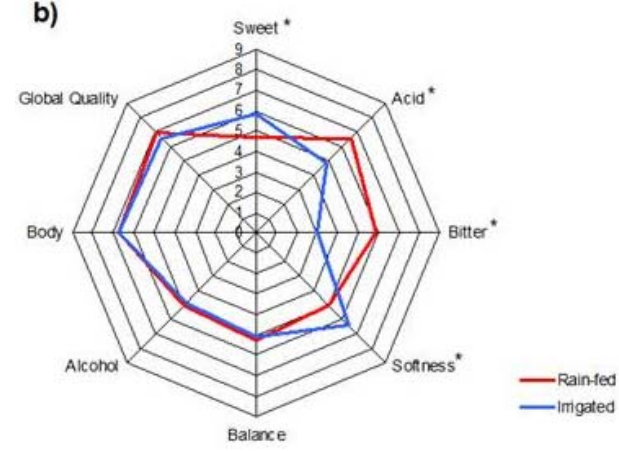

Figure 4. Sensory profiles of 'Godello' wines from 2012 as a function of the irrigation treatment: a) aroma attributes; b) mouth attributes and global quality. Descriptors marked with an asterisk differed significantly between treatments $(\mathrm{p}<0.05)$.

Perfis sensoriais dos vinhos ‘Godello’ 2012 em relação ao tratamento de rega: a) atributos do aroma; b) atributos gustativos e qualidade global. Os descritores marcados com um asterisco

diferiram significativamente entre tratamentos $(\mathrm{p}<0.05)$.

'Treixadura' wines from 2011 and the rain-fed treatment presented fresh fruit and herbaceous notes; whereas those from the irrigation treatment were better marked for white fruit and persistence, even though they presented terpenic notes (Figure 5). However, tasters did not gave different marks for global quality to wines from any of the treatments. This indicates that the chemical differences observed were not enough to be detected at the sensory level as reported in a former study (Blanco et al., 2012), where panelists were not able to found noticeable differences in wine mouth attributes for 'Treixadura' wines fermented with different yeasts.

Finally, 'Treixadura' rain-fed wines from 2012 presented terpenic notes and those from the irrigation treatment were better marked for floral, white fruit, tropical and persistence (Figure 6). Therefore, wines from the irrigation treatment obtained a higher mark of global quality than those from the rain-fed treatment.

Even though differences for most of the descriptors were not significant between rain-fed and irrigation treatments, some descriptors were evaluated differently depending on the imposed treatment. This fact was possibly caused by an effect of the taster, as previously reported by Vilanova (2006) for herbaceous or citric. Moreover, the high value for total acidity could have masked the sensory perception of the alcohol content.
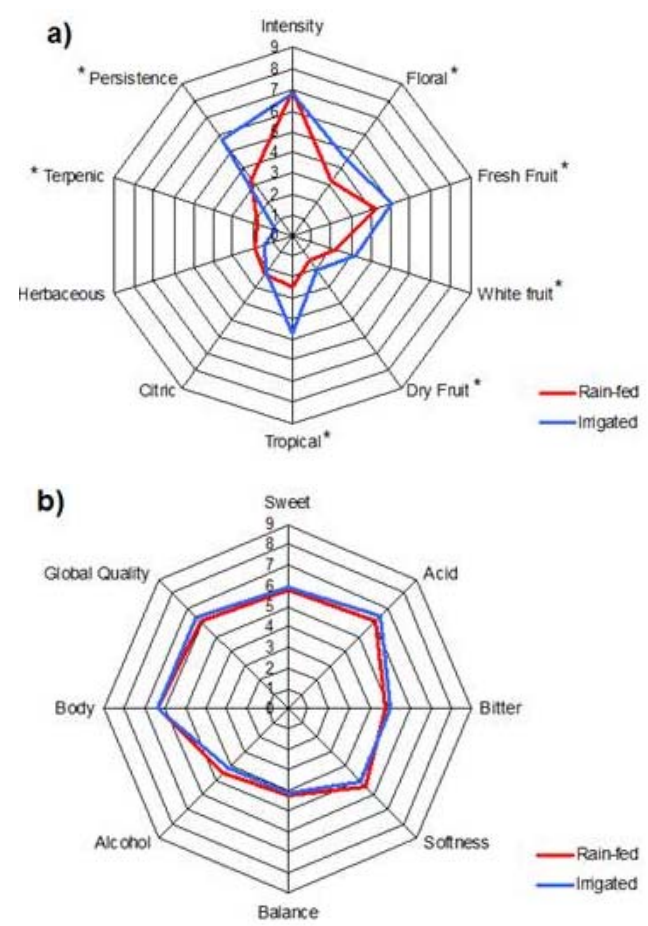

Figure 5. Sensory profiles of 'Treixadura' wines from 2011 as a function of the irrigation treatment: a) aroma attributes; b) mouth attributes and global quality. Descriptors marked with an asterisk differed significantly between treatments $(\mathrm{p}<0.05)$.

Perfis sensoriais dos vinhos 'Treixadura' 2011 em relação ao tratamento de rega: a) atributos do aroma; b) atributos gustativos e qualidade global. Os descritores marcados com um asterisco diferiram significativamente entre tratamentos $(\mathrm{p}<0.05)$.

Furthermore, the fact that certain descriptors such as flower, fresh fruit and citric were more intense in wines from the rain-fed treatments might indicate a greater concentration of these aroma compounds, as previously reported by Jackson and Lombard (1993). In addition, the content of such compounds as linalool, which is high in Galician wines (Versini et al., 1994), might have been greater in wines from the rain-fed treatments and, thus, more intense to the tasters. However, in 2012 we observed slight differences between treatments for the three cultivars which might be caused by the low yield obtained in both treatments that could have counteracted the irrigation effect on the sensory profiles of the wines.

Hedonic index is computed using several descriptors and it permits to assess tasters' preference for a given wine (Odello et al., 2009). These descriptors differed each year and for each variety.

In 2011, a high number of descriptors influenced the calculation of the hedonic index. In the case of 'Albariño' wines, 11 descriptors were involved in the hedonic index: intensity, floral, terpenic, persistence, sweet, acid, softness, balance, alcohol, body and global quality. For 'Godello', 8 descriptors were included in the hedonic index: intensity, fresh fruit, persistence, softness, balance, alcohol, body and 
global quality. Finally, for 'Treixadura' wines, 6 descriptors were involved in the hedonic index: floral, fresh fruit, sweet, balance, body and global quality. Despite this number of descriptors, only three were common for the three cultivars: balance, body and global quality.
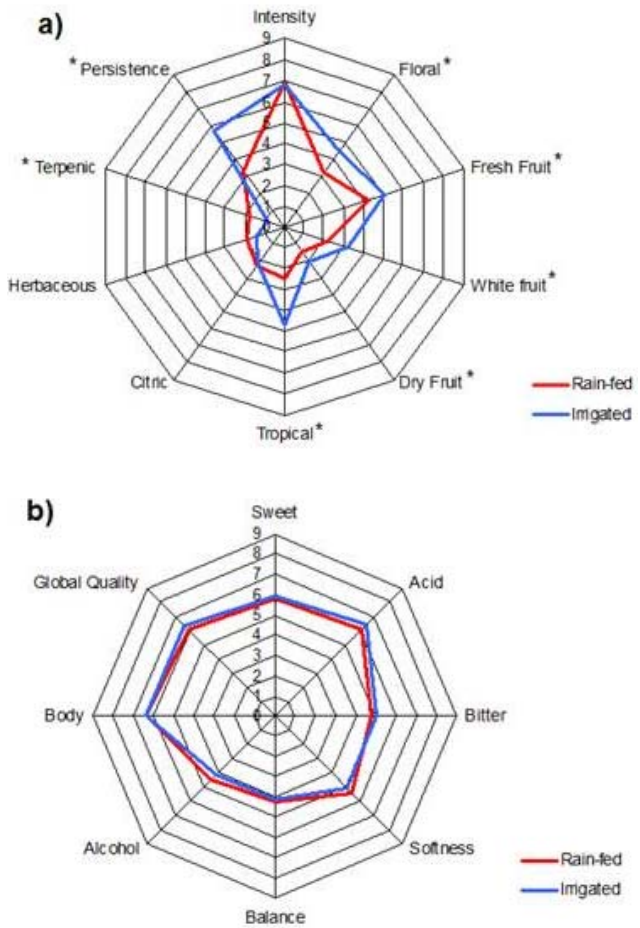

Figure 6. Sensory profiles of 'Treixadura' wines from 2012 as a function of the irrigation treatment: a) aroma attributes; b) mouth attributes and global quality. Descriptors marked with an asterisk differed significantly between treatments $(\mathrm{p}<0.05)$.

Perfis sensoriais dos vinhos 'Treixadura' 2012 em relação ao tratamento de rega: a) atributos do aroma; b) atributos gustativos e qualidade global. Os descritores marcados com um asterisco diferiram significativamente entre tratamentos $(\mathrm{p}<0.05)$.

In 2012, in the case of 'Albariño' and 'Treixadura', those descriptors were: floral, fresh fruit, white fruit, dry fruit, softness, balance, alcohol and body. In the case of 'Godello' wines, the descriptors were: floral, fresh fruit, sweet, softness, balance and alcohol. Several of these descriptors were common for the three cultivars: floral, fresh fruit, softness, balance and alcohol.

The only descriptor that had a significant effect on the hedonic index for both vintages was balance.

The values of the hedonic index were greater for rainfed wines than for those from the irrigated treatment in the cases of 'Albariño' and 'Godello' wines for both vintages (Table V). These differences were significant for 'Albariño' in 2011 and for 'Godello' in both years. However, 'Treixadura' wines from the irrigation treatment in 2012 obtained a slightly higher hedonic index than those from the rain-fed treatment, but this difference was not significant (Table V). These results are in accordance with the preference of the tasters, displayed in the sensory profiles of the wines.

Several of the descriptors involved in the calculation of the hedonic index were common for the three varieties: floral, fresh fruit, softness, balance, alcohol, body and wine global quality. This suggests that those attributes are the most important for the tasters and, some of them, were also found by other authors (Vilanova et al., 2013).

\section{CONCLUSIONS}

This research allowed us to obtain the sensory profiles for wines from three Galician white cultivars under different irrigation conditions in two consecutive vintages. In the case of 'Albariño' and 'Godello' wines, the rain-fed treatment received higher marks than the irrigation treatment for both studied years. However, 'Treixadura' wines from the rain-fed treatment were better marked in 2011, whereas those from the irrigation treatment were better marked in 2012. The differences observed at the sensory level corresponded to those suggested by the chemical parameters of wines. Three descriptors influencing the hedonic index were common for the three cultivars.

\section{ACKNOWLEDGEMENTS}

This study was funded by the Spanish Instituto Nacional de Tecnología Agraria y Alimentaria (INIA) project reference RTA2011-00041-C02-01, with 80\% FEDER funds. E. Trigo-Córdoba and Y. Bouzas-Cid thank INIA for their PhD. grants. J.M. Mirás-Avalos thanks Xunta de Galicia for his contract within the framework of the "Isidro Parga Pondal" programme.

\section{REFERENCES}

Allen R.G., Pereira L.S., Raes D., Smith M., 1998 Crop evapotranspiration: guidelines for computing crop water requirements. Irrigation and Drainage Paper 56. 300 p. United Nations FAO, Rome.

Blanco P., Mirás-Avalos J.M., Suárez V., Orriols I., 2012. Inoculation of Treixadura musts with autochthonous Saccharomyces cerevisiae strains: Fermentative performance and influence on the wine characteristics. Food Sci. Technol. Int., 19, 177-186.

Borghezan M., Pit F.A., Gavioli O., Malinovski L.I., Lima da Silva A., 2011. Effect of leaf area on the grape composition and sensory quality of wines from cultivar Merlot (Vitis vinifera L.) in São Joaquim, SC, Brazil. Ciência Téc. Vitiv., 26, 1-9.

Choné X., van Leeuwen C., Dubourdieu D., Gaudillère J.P., 2001. Stem water potential is a sensitive indicator of grapevine water status. Ann. Bot., 87, 477-483.

Consello Regulador Ribeiro, 2014. Retrived from: www.ribeiro.es [accessed in $14^{\text {th }}$ February 2014].

Cruz R., Lago A., Rial M.E., Díaz-Fierros F., Salsón S., 2009. Evolución recente do clima de Galicia. Tendencias observadas en variables meteorolóxicas. In: Evidencias e Impactos do Cambio Climático en Galicia. 19-58. Consellería de Medio Ambiente e Desenvolvemento Sostible, Santiago de Compostela. 
Falqué E., Fernández E., Dubourdieu D., 2001. Differentiation of white wines by their aromatic index. Talanta, 54, 271-281.

Falqué E., Fernández E., Dubourdieu D., 2002. Volatile components of Loureira, Dona Branca, and Treixadura wines. J. Agric. Food Chem., 50, 538-543.

García-Muñoz S., Muñoz-Organero G., Fernández-Fernández E., Cabello F., 2014. Sensory characterisation and factors influencing quality wines made from 18 minor varieties (Vitis vinifera L.). Food Qual. Pref., 32, 241-252.

Gouveia J., Lopes C.M., Pedroso V., Martins S., Rodrigues P., Alves I., 2012. Effect of irrigation on soil water depletion, vegetative growth, yield and berry composition of the grapevine variety Touriga Nacional. Ciência Téc. Vitiv., 27, 115-122.

Hopfer H., Heymann H., 2014. Judging wine quality: Do we need experts, consumers or trained panelists? Food Qual. Pref., 32, 221233.

Intrigliolo D.S., Castel J.R., 2010. Response of grapevine cultivar 'Tempranillo' to timing and amount of irrigation: water relations, vine growth, yield and berry and wine composition. Irrig. Sci., 28, 113-125.

ISO, 1977. ISO norm 3591: Sensory analysis: apparatus wine tasting glass. International Organization for Standardization, Genève.

ISO., 1988. ISO norm 8589: Sensory analysis: general guidance for the design of test rooms. International Organization for Standardization, Genève.

Jackson D.I., Lombard P.B., 1993. Environmental and management practices affecting grape composition and wine quality: A review. Amer. J. Enol. Vitic., 44, 409-430.

Junquera P., Jiménez L., Linares R., Baeza P., Lissarrague J.R., 2012. Long-term effects of different irrigation strategies on yield components, vine vigour, and grape composition in cv. Cabernet sauvignon (Vitis vinifera L.). Irrig. Sci., 30, 351-361.

López-Tamames E., Carro-Mariño N., Ziya Gunata Y., Sapis C., Baumes R., Bayonove C., 1997. Potential aroma in several varieties of Spanish grapes. J. Agric. Food Chem., 45, 1729-1735

Martínez E.M., Rey B.J., Fandiño M., Cancela J.J., 2012. Evaluación del estado hídrico de los viñedos en el noroeste de España. Las denominaciones de origen a examen. Interempresas Industria Vitivinícola, 10, 50-58.

Mirás-Avalos J.M., Mestas-Valero R.M., Sande-Fouz P., PazGonzález A., 2009. Consistency analysis of pluviometric information in Galicia (NW Spain). Atmos. Res., 94, 629-640.
Mirás-Avalos J.M., Trigo-Córdoba E., Bouzas-Cid Y., 2014. Does predawn water potential discern between irrigation treatments in Galician white grapevine cultivars? J. Int. Sci. Vigne Vin, 48, 123127.

Mirás-Avalos J.M., Trigo-Córdoba E., Bouzas-Cid Y., RegoMartínez F., Díaz-Losada E., 2012. Efectos del riego sobre tres variedades blancas autóctonas gallegas (Treixadura, Godello y Albariño) en la D.O. Ribeiro: primeros resultados. Interempresas Industria Vitvinícola, 12, 20-27.

Odello L., Braceschi G.P., Seixas F.R.F., da Silva A.A., Galinaro C.A., Franco D.W., 2009. Avaliação sensorial de cachaça. Quím. Nova, 32, 1839-1844.

Odello L., Ugolini A., Violini M., 2007. Analisi Sensoriale. I test descrittivi. Centro Studi Assaggiatori, Brescia.

OIV, 2009. Compendium of International Methods of Wine and Must Analysis. Vols. 1 and 2. Office International de la Vigne et du Vin, Paris.

Pazo M., Montero E., Traveso C., Vaamonde A., 2004. Perfil de aminoácidos libres de los vinos Albariño y Godello. Aliment., 357, 111-117.

Perrin L.M., Symoneaux R., Maitre I., Asselin C., Jourjon F., Pages J., 2007. Comparison of conventional profiling by a trained tasting panel and free profiling by wine professionals. Am. J. Enol. Vitic., 58, 508-517.

Soil Survey Staff, 2010. Keys to Soil Taxonomy. 346 p. United States Department of Agriculture, National Resources Conservation Service.

Versini G., Orriols I., Dalla Serra A., 1994. Aroma components of Galician Albariño, Loureira and Godello wines. Vitis, 33, 165-170.

Vilanova M., 2006. Sensory descriptive analysis and consumer acceptability of godello wines from Valdeorras apellation origen controlée (Northwest Spain). J. Sens. Stud., 21, 362-372.

Vilanova M., Vilariño F., 2006. Influence of geographic origin on aromatic descriptors of Albariño wines. Flav. Frag. J., 21, 373378.

Vilanova M., Escudero A., Graña M., Cacho J., 2013. Volatile composition and sensory properties of North West Spain white wines. Food Res. Int., 54, 562-568.

Vilanova M., Zamuz S., Tardáguila J., Masa A., 2008. Descriptive analysis of wines from Vitis vinifera cv. Albariño. J. Sci. Food Agric., 88, 819-823. 